This is an open access article under the CC BY-NC-ND license (https://creativecommons.org/licenses/by-nc-nd/3.0/) Issue III, November 2020

ISSN 2707-9481

ISBN 978-601-323-207-2

https://doi.org/10.31643/2020.030

\author{
Meruert A. Abisheva \\ Al-Farabi Kazakh National University \\ Email: abisheva_meruyert2@live.kaznu.kz \\ ORCID ID https://orcid.org/0000-0002-2765-9054
}

\author{
Fathimah D. Pertiwi \\ Yogyakarta State University, Indonesia \\ Email: fathimdp28@gmail.com \\ ORCID ID https://orcid.org/0000-0002-4604-3167
}

\title{
Features of Modern Management
}

\begin{abstract}
Management is an individual or group of individuals that accept responsibilities to run an organization. Management is essential not only for business concerns but also for banks, schools, colleges, hospitals, hotels, religious bodies, charitable trusts etc. Every business unit has some objectives of its own. Management is a vital aspect of the economic life of man, which is an organised group activity. It is considered as the indispensable institution in the modern social organization marked by scientific thought and technological innovations. One or the other form of management is essential wherever human efforts are to be undertaken collectively to satisfy wants through some productive activity, occupation or profession. This study using descriptive method. Descriptive method is a technique used on finding the elements, characteristic and nature of a phenomenon. The purpose of this study is to provide a profile of a phenomenon or to explain its relevant aspects based on individual perspective, organizational, industrial, or any other perspective. Modern management has many new principles compared to traditional management, which include responsibility, which is explained as a prerequisite for successful management, loyalty to employees, an atmosphere that promotes the disclosure of employee abilities, communication that permeates the organization from top to bottom, from bottom to top and horizontally, the participation of each employee in the overall results, timely response to changes in the environment, the ability to contact suppliers, buyers, performers and managers, business ethics, methods of working with people, they are aimed at creating job satisfaction, direct participation of managers in group work, honest attitude and trust in people, using the fundamental principles of management in their work, a clear understanding of the place and role of the organization in the future, the quality of personal work and continuous self-improvement.
\end{abstract}

Keywords: Traditional management, modern management, history of management.

\section{Introduction}

Management as an independent type of professional activity, today must form the values, directions and traditions of individuals, entire organizations and society, make them more productive. To put it another way, in the case when the management is unable to mobilize the specific cultural heritage of a particular country and people, then the economic and social development of countries and peoples can be under great threat.

Traditional management, which has been used for many years, has been replaced by modern management, which is more complex than the previous one. Compared to traditional management, which is based on the representation of the management process in the form of managers performing a number of functions, including planning, organizing, monitoring implementation, as well as coordination and activation, the functions of modern management include a wider range of functions that are constantly being updated and expanding. 


\section{The purpose of the study}

The purpose of this study is to provide a profile of a phenomenon or to explain its relevant aspects based on individual perspective, organizational, industrial, or any other perspective.

\section{Methodology and research methodology}

This study using descriptive method. Descriptive method is a technique used on finding the elements, characteristic and nature of a phenomenon. Descriptive study also known as a study that explain a phenomenon as original as it is, a straight fact, to explain the characteristic of various variables in a research in a certain situation. The purpose of this study is to provide a profile of a phenomenon or to explain its relevant aspects based on individual perspective, organizational, industrial, or any other perspective (Ali dan Limakrishna, 2013: 76).

\section{Results of the study}

According to Henry Fayol, the definition of management is to forecast and plan, to organize, to command, to co-ordinate and to control. To foresee and provide means examining the future and drawing up the plan of action. To organize means building up the dual structure, material and human, of the undertaking. To command means maintaining activity among the personnel. To co-ordinate means binding together, unifying and harmonizing all activity and effort. To control means seeing that everything occurs in conformity with established rule and expressed command (Fayol, 1916: 5-6). In Addition, Bedelan definition about management is process of achieving desired results through efficient utilization of human and material resources (Kaehler \& Grundei, 2019).

Management today is a "person-filled" model and the presence of a person in decision-making in the field of management is key and significant (Bochkarev A., Kondratev V., 2008). Management solutions from the beginning of the XX century that have shown great efficiency: functional regulation of work; budgeting; accounting for expenses and income; distribution of expenses and income across the company; financial and economic review of work; organizational foundations that study the areas of responsibility of all participants well; confirmation of employees ' compliance with the conditions that are promoted to these employees - that is, management methods of the early $\mathrm{XX}$ century, this set of methods created the most necessary conditions for the competitiveness of companies of that century. After that, 50 years have passed, the supplier's market has moved to the buyer's market. It was necessary to create new areas of management - strategic management. Mixed modern economies of different countries can be described as an economy, but the US or The German economy is not in transition. New preconditions for the economic system and the new system as a special embryo that develops independently without each other. Market economy in this case, the state limits the price and prohibits it from "exceeding production costs". Sellers reimbursement of expenses from the state budget fills in. This is the experience of developed countries common to all (Sakhariev S. S., Sakharieva A. S.- , 2003.). Today we are again seeing big changes in the market. This market is being globalized. The digital economy is emerging in this market. In this market, many processes are performed not in the traditional way, as everyone is used to, but with the use of computers, robots and new industrial models, that is, in modern management.

Modern management refers to the development and creation of economic systems, as well as the maximum use and management of socio-economic systems, which include government, commercial and noncommercial spheres of activity (Certo, S., 2006). The original concepts of modern management include: that any employee of the company is, first of all, a person with his diverse needs, and only in the last place is a "tool" for ensuring profit, this makes it clear that the role of the human factor as a key resource has led to the need to create real conditions to realize the potential of self-development inherent in a person, secondly, the development of an action strategy that makes up the most necessary plans and programs, and the goals are focused on improving individual skills and the external environment of the organization is extremely changeable and mobile. The foundations of modern management were laid by the classics Frederick Taylor, Garrington Emerson, Geri Ford, and Henri Fayol.

Modern management includes flexibility as well as the ability to adapt, that is, to look everywhere for new opportunities, welcome changes and adapt your style to the needs of other people, when traditional management is described as rooted in a hierarchical structure that constantly produces order and control among 
its employees, that is, it is studied as hierarchy and organization. Transformative and authentic, this is explained as demonstrating a genuine desire to support the development of other people by combining individual motivation with the goals of organizations, at a time when the traditional approach is represented by power and authority, that is, demonstrate power and authority in decision-making in the organization, and are internally motivated to achieve power and career growth. Collaborative and conscious this is defined as the focus on inspiring and developing knowledge, as well as the skills and abilities that are necessary to support individuals and teams in achieving goals, while the traditional approach is explained by process and results management, that is, responsibility for developing processes that activate the organization's performance and deliver results. Empowerment and innovation is studied as giving teams the opportunity to creatively solve problems and empower others by delegating authority, while the traditional approach is portrayed as command and control, that is, maintaining and exercising authority through the management and command approach. Goals based on team dynamics and performance are defined as goals and objectives focused on improving individual and team skills to achieve optimal team performance, while the goals of the traditional approach are based on policy as well as results. goals and objectives focus on sales, profits, policies, and organizational products.

Modern management has many new principles compared to traditional management, which include responsibility, which is explained as a prerequisite for successful management, loyalty to employees, an atmosphere that promotes the disclosure of employees ' abilities, communication that permeates the organization from top to bottom, from bottom to top and horizontally, the participation of each employee in the overall results, timely response to changes in the environment, the ability to contact suppliers, buyers, performers and managers, business ethics, methods of working with people, they are aimed at creating job satisfaction, direct participation of managers in group work, honest attitude and trust in people, using the fundamental principles of management in their work, a clear understanding of the place and role of the organization in the future, the quality of personal work and continuous self-improvement (Hoechlin N., Core 2018).

The intellectual nature of decision-making processes, this feature is manifested at the moment when intellectual resources are attracted to the planning sphere, that is, the transition to multi-purpose plans that take into account the inconsistency of management decisions and their multiple different consequences. A decision that is only effective in one area may lead to negative consequences or reduced effectiveness in other areas. In the traditional management of universal factor is almost not taken into account. However, if several goals are mentioned, these goals are considered separately as a set, and planning is based on ready-made samples, which leads to errors and reduced efficiency. For example, if you take one of the mistakes of traditional planning-this is the use of a one-condition approach, when only one condition is taken into account, such as profit or income. As a result, they achieve one goal, for example, they concentrate on expanding production by reducing investment in its renewal, and then, lagging behind competitors who quickly update their products, they incur losses instead of making profits. The principles of modern management include the continuity and ubiquity of certain innovative processes that are located within the organization (Hawk R., 2020). These innovations should be created not only by certain departments and development services but also become the main daily tools for increasing internal efficiency and competitiveness of all departments. In particular, the development of any organization without the organization of certain innovative processes condemns it to the loss of market positions.

Modern management is based on education in the management systems of an intelligent center, which includes a network of teams that bring together talented managers and good specialists who are able to choose the right development option at the moment, solve both current and future problems of the entire organization. A single manager cannot solve all management tasks, and a single team cannot cover the entire range of development problems, including the presence of a single team, even for a medium-sized company, is absolutely not enough (Magretta J., 2002). Teams must be highly specialized in order to flexibly change their structures. In addition, just one team means that there is no network of teams within the organization, but there is an administrative group that has a good influence on the staff, including one formed under the manager to confirm and support his management decisions. In this team, all employees are aware of what to say and how to say it so that the manager likes it. The culture of modern management is based on many interests.

The divergence of the once unified system of General management and the emergence of new types of management, such as investment management, marketing, innovation, and others. The modern approach of management is a complex structure that includes various means of systemic influence on the organization, ensuring the growth of their competitiveness. At that time, individual management functions were transformed into unified systems as it developed. In recent years, marketing management has emerged on the basis of 
marketing, logistics management on the basis of logistics methods, innovation management on the basis of planning and implementation of innovations, and many other types.

Increasing the functions of managers, reworking their structure and the emergence of new functions, which is associated with the difficulty of the management environment, the need to maximize the use of all internal reserves of managers, as well as the percentage of managers ' influence on the final results, including the need to increase the intellectual level of management and the qualification of managers. Traditional management functions include planning, organization, control, and coordination. The functions of a modern Manager are significantly expanded, internal processes of their integration and the emergence of new ones are always taking place.

In modern management, there are many new functions of managers. Response to changes and threats in the external and internal environment, this is understood as the need to develop the ability to flexibly change the organization strategy in those conditions in which new threat factors appear, including timely readiness to counter these threats. Threats can have both external and internal origins in the organization. Competition is studied as the actions of all managers that are aimed at increasing the competitiveness of a particular Department, taking into account the achievements of different divisions of organizations that are leading. For example, competition in well-performing organizations is not only external, but most importantly internal, that is, it begins at the workplaces of managers in organizations. In modern management, a new factor is the development of the structure of civilized competition, which is based on open competition and can be added to the comparison of the results of different managers of the organization, with the growth of individual competitiveness. Network and interpersonal communications in modern management include the exchange of information in a way that involves personal communication and through computer information networks, which greatly reduces the time and increases certain opportunities for using large amounts of information.

Continuous training and self - learning is a new function of the Manager in the conditions of operational modernization of production, products, the emergence of new approaches and management technologies. The social responsibility of a Manager indicates that they are aware of a specific role in influencing the personalities of other people who are under their control, in showing them demands (Bringham, F. E \& Houston F. Joel. 2018). Social responsibility is also described as following universal values in management. Logistics functions include the complex provision of the organization's employees with everything they need, including various resources, industrial facilities, necessary materials and information.

The growth of self-management of individuals and teams provides greater independence for managers, aimed at the strategic goals of the organization, the system of influence on the formation of human capital of the organization, attracting personnel to the management process, increasing the stability of the Manager's personality to opposite environmental influences, excess information, conflicts and other factors. Working in a network of objects includes the Manager's participation in various objects that are aimed at solving the problems of the company's development and its division (Turner, J.,2019). These objects should not be based on samples, but on the application of complex, intelligent approaches and technologies. The most important goal is to achieve maximum competitive advantages. Object management approaches and technologies leave the intellectual capacity of all organizations and are among its most valuable intangible assets. Creating a good image of the company and the Manager includes the work of the Manager, which ensures the strengthening of the company's market position and its own position in it. Various mistakes of a Manager in communicating with just one consumer can lead to a General decrease in the company's image, as well as the loss of a significant market share, and a decrease in investment in it.

In the modern management approach, active development and formation of self-management within the organization in certain types: from teams of managers and employees, self-managed decentralized departments, including business units, investment institutions, responsibility institutions, development of team ownership forms, when employees become owners of the company in which they work. Development of selfmanagement is one of the most important features of modern management. In contrast to other organizations, where decisions are mostly made exclusively by management, for example, in foreign companies, there is an increasing tendency to transfer parts of the resolution, including strategic ones, to branches. The involvement of personnel in management leads to an increase in productivity and quality of work, reduces costs, but also increases efficiency and returns on invested funds.

The status of the social position of management within the organization and in relation to society. Organizations that follow the policy of attitude to their managers lag behind leading companies that strive to create an atmosphere of collective character and partnership in everything, attract employees to participate in the income and ownership of the company, create a long-term perspective in leadership qualities to improve the standard of living and comfort. In a state of competition, the company's social image in society becomes an essential element of competitive advantage. 
The use of information technologies in the modern approach of management, which qualitatively change the structure of labor, accelerate the exchange of information and communication, reduce the risk and indeterminacy caused by a lack of information in management decision-making. Management is a constant searching for new ways to make your company more competitive, and it is impossible to achieve this without creating a more competitive management.

\section{History of Management}

Management ideas and practice have been used from earliest times recorded history. The basic idea was to use flute, drum, or song lyrics to pace people to work in unison using the same efficient motions, to stimulate the to work faster and longer, and to make the boring work more fun (Ali, M, no year). Management and business history had a far more limited geographical and temporal perspective than either of its two comparator fields of inquiry. More encouragingly though, we found signs that greater diversity in management history is certainly possible and that it may now be emerging (Cummings, Hassard \& Rowlinson, 2017).

There are four different approaches in the history of management:

1. The approach from the point of view of highlighting numerous schools in management includes almost four different interesting approaches. This approach to management describes management from four different perspectives: the school of scientific management, administrative management, human positions and management science, or quantitative approaches (late 19th century-present);

2. The process approach explains management as a constant set of interrelated management functions (20s of the XX century-to the present);

3. The systems approach describes that managers of an organization should view an organization as a collection of interdependent elements, such as people, composition, tasks, and technologies that are focused on achieving certain goals in different environments (50-60 years). XX century-to the present);

4. The situational approach is based on the fact that the suitability of various management methods is determined by the situation. The most effective approach to the situation is the method that best corresponds to this situation (60s of the XX century-to the present).

Modern management should contribute to the development of the market, convertibility and stabilization of market prices. The most important aspect of the development of modern management is the strengthening of the technocracy structure, which occurs when innovative management technologies are introduced at an information technology facility. This fact speaks in favor of a strategic approach to managing both vertical and horizontal strategies-the business of all employees (Zhuo J.,2019) Before implementing this management system, organizations planned their work. Strategic management at a certain point studies how an organization should perform well in modern conditions in order to achieve the desired goal in the future. strategic management measures the current state. However, it not only predicts the desired status in the future, but also develops the ability to adequately respond to small changes in the external environment of the organization in order to achieve the goals set.

The innovative nature of modern management, dependence on employees, a certain social environment bring to the first place skills of a special kind. In other words, the task of a modern Manager is to create conditions under which even the most ordinary people can achieve extraordinary results. Subordinates with the help of managers should develop from simple controlled employees of the company into good specialists with excellent authority. A modern Manager needs to be clear about exactly what behavior he wants from the subordinate to achieve and what it should teach, as a modern Manager should know how his staff has actually why it is necessary to control not so much the results as the process of its work, should be able to analyze the causes of improper actions of the subordinate and to be ready to receive information about wrong-doing, must learn to teach, that is, personal involvement in staff development should be perceived by them as an important strategic function. A modern Manager should build a relationship with subordinates that will not only not lose control of the situation when transferring more knowledge and authority to subordinates, but also make it even more controlled.

\section{Conclusion}

The world we live in is a world of modern management, a new world. It reflects the fact that we live in a very complex and rapidly changing world, in which we are subject to changes in accordance with which this world exists and develops. The main thing is to succeed in this new world, you need to study well, develop and become a good Manager. 
Cite this article as: Abisheva M. A., Pertiwi F. D. (2020) Features of Modern Management. Materials of International Practical Internet Conference “Challenges of Science”. Issue III, 2020. Pp.: 195-200.

https://doi.org/10.31643/2020.030

\section{References}

[1] 7 notes of management / Bochkarev A., Kondratev V.-Eksmo, 2008

[2] World economy / Sakhariev S. S. Sakharieva A. S.- Almaty, 2003.

[3] Bringham, F. E \& Houston F. Joel. Fundamentals of Financial Management/ Eugene F. Cengage Learning. 2018

[4] Certo, S. Modern Management. Pearson. 2006

[5] Cummings, S., Hassard J., \& Rowlinson M. A new History of Management. Cambridge University Press. 2017.

[6] Hawk, R. Welcome to Management. McGraw-Hill Education, 2020

[7] Hoechlin, N. Core Leadership and Management Skills, Tips \& Strategy Handbook. JNR Publisher. 2018

[8] Kaehler, B \& Grundei J. HR Governance: A Theoritical Introduction. Springer. 2019. http://dx.doi.org/10.1007/978-3-31994526-2

[9] Magretta, J. What Management Is. Simon and Schuster. 2002.

[10] Muhammad, Ali, The History of Management. No year.

[11] Turner, J. Agile Project Management/ International Consulting Ltd. 2019

[12] Zhuo, J. The Making of a Manager: What to Do When Everyone Looks to You. Portfolio. 2019 